\title{
Borehole video observation of englacial and basal ice conditions in a temperate valley glacier
}

\author{
Luke Copland, ${ }^{1 *}$ Jon Harbor, ${ }^{1}$ Martin Sharp ${ }^{2}$ \\ ${ }^{1}$ Department of Earth and Atmospheric Sciences, Purdue University, West Lafayette, IN 47907, U.S.A. \\ ${ }^{2}$ Department of Earth and Atmospheric Sciences, University of Alberta, Edmonton, Alberta T6G 2E3, Canada
}

\begin{abstract}
As part of a study of ice dynamics, 25 boreholes were drilled with highpressure hot water to the base of Haut Glacier d'Arolla, Switzerland. The boreholes were distributed across a half-section of the glacier, with closest spacing towards the glacier margin. The interior structure of the glacier was investigated by lowering a miniature color video camera down 11 boreholes, and the glacier bed was observed in 3 boreholes.

The video showed distinct changes in ice conditions with depth in the glacier, including ice foliations and changes in ice-bubble content and color. A basal ice layer of varying thickness was recorded in two of the three boreholes in which the glacier bed was observed. This basal ice layer was characterized by relatively sediment-rich, coarse-clear ice, and was thickest in a zone of high water-pressure fluctuations. The available evidence suggests that localized freezing at the glacier bed caused by variations in water pressure is the primary source of this basal ice layer. The near-surface transition between finegrained and coarse-bubbly ice, and between coarse- bubbly and coarse-clear ice, appeared to correlate with the depths of influence of diurnal and annual cold waves, respectively. Two types of ice foliation were identified, consisting of distinct planar coarse-clear ice, or more pervasive coarse-bubbly or fine-grained ice. An origin from crevasse closure or the transposition of sedimentary stratification provides the most likely explanation for these.
\end{abstract}

\section{INTRODUCTION}

A good knowledge of glacier dynamics is important for understanding a variety of glaciological processes and characteristics. For example, an understanding of the processes of debris entrainment and deposition by ice is important for the interpretation of glacial deposits (Menzies, 1995). One way in which glacier dynamics can be investigated is to analyze the physical structure and characteristics of glacier ice that exists today. This ice contains the evidence of processes such as basal sliding, internal deformation and debris entrainment.

A variety of techniques have been used to study the internal structure of glaciers. The difficulty of accessing the interior or base of a glacier has meant that many studies have relied on observations from the glacier surface or marginal ice cliffs (e.g. Allen and others, 1960; Boulton, 1970). In an effort to improve understanding of the conditions and processes below the glacier surface, several studies have focused on direct observation of conditions at the glacier bed, via tunnels drilled to the bed (Kamb and LaChapelle, 1964; Boulton and others, 1979; Goodman and others, 1979; Hagen and others, 1983), or via natural subglacial cavities (Vivian and Bocquet, 1973; Anderson and others, 1982; Jouzel and Souchez, 1982; Tison and Lorrain, 1987; Rea and Whalley, 1994). Studies based on surface and marginal ice

* Present address: Department of Earth and Atmospheric Sciences, University of Alberta, Edmonton, Alberta T6G 2E3, Canada. structure are limited by the lack of subsurface observations, however, whereas studies at the glacier bed typically only provide information about a single location. Ice coring has provided a partial solution via analysis of the extracted ice (e.g. Koerner, 1977), although the spatial resolution of the records is often limited as it is rare for more than a few cores to be drilled within a single field season. Conditions surrounding the ice core are also commonly unknown, although borehole photography has provided some insights (Harrison and Kamb, 1973; Engelhardt and others, 1978; Koerner and others, 1981).

Hot water drilling can solve some of these spatial resolution problems by allowing the drilling of many boreholes to the glacier bed within a single field season. The combination of a miniature video camera and many accessible boreholes can therefore provide spatially detailed observations of the internal structure of a glacier (Koerner and others, 1981; Pohjola, 1993, 1994; Harper and Humphrey, 1995; Copland and others, in press). The advantages of borehole video are that it provides a continuous record of ice structure with depth, and real-time viewing that allows concentration on areas of interest as they are encountered. This paper describes borehole video observations across a section of Haut Glacier d'Arolla, Switzerland, and how these observations provide information about the structure and dynamics of a temperate valley glacier.

\section{FIELD SITE AND METHODOLOGY}

Haut Glacier d'Arolla is a temperate valley glacier located in southern Switzerland (Fig. 1). It is approximately $4.5 \mathrm{~km}$ 


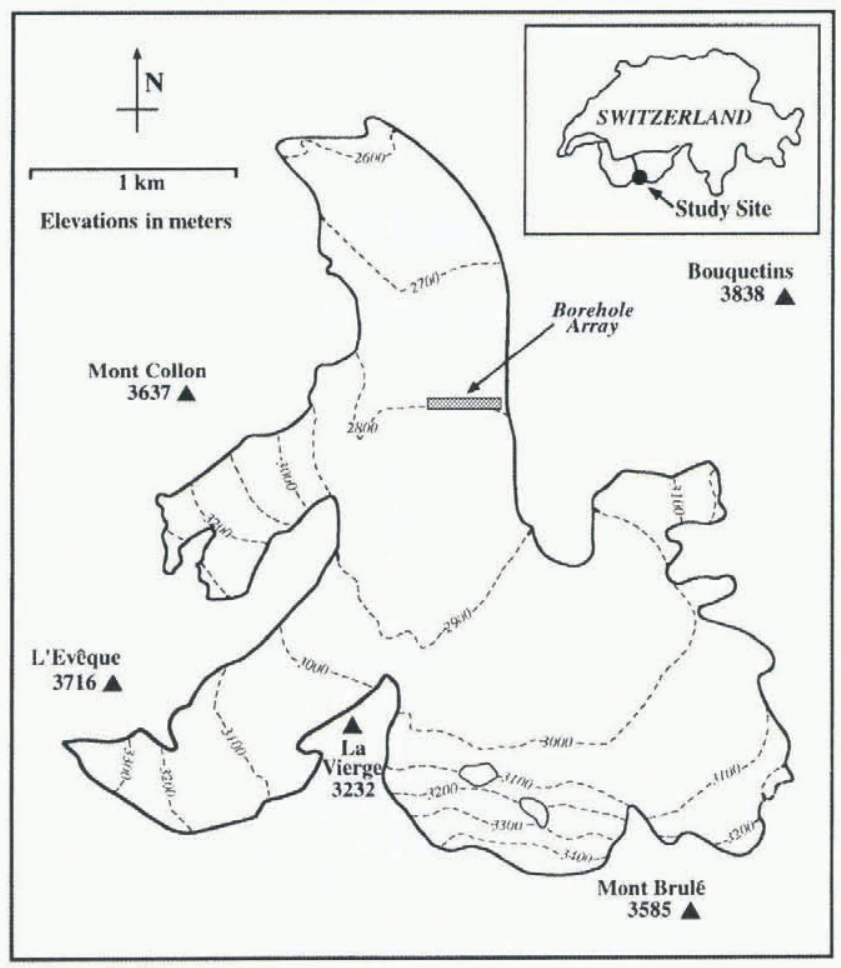

Fig. 1. Map of Haut Glacier d'Arolla. The 1995 borehole array was located towards the eastern margin of the glacier, approximately $1.5 \mathrm{~km}$ from the terminus.

long, covers an area of $6.3 \mathrm{~km}^{2}$, and ranges in elevation from 2560 to $3500 \mathrm{~m}$. Since 1992 a hot water drilling program has focused on an area of the glacier $1.5 \mathrm{~km}$ from the terminus, in the ablation zone. Approximately 25 boreholes have been drilled per year, and these have been used in a variety of studies to provide information about the hydrology and dynamics of the glacier (Hubbard and others, 1995; Lamb and others, 1995; Copland and others, 1997, in press; Tranter and others, in press). A total of 25 boreholes were drilled to the glacier bed with high-pressure hot water in July and August 1995, of which 11 were investigated with a miniature video camera. The boreholes were located across a half-section of the glacier, with closest spacing towards the glacier margin (Fig. 2). This spacing was based on the needs of other studies that focused on measuring borehole-deformation patterns for use in numerical modeling (Copland and others, 1997), and hydrological studies that had previously identified a major subglacial channel towards the eastern margin of the glacier (Hubbard and others, 1995).

A GeoVision Micro ${ }^{(i x)}$ borehole video-camera system, manufactured by Marks Products Inc., and supplied by Colog Inc., was used to observe the interior of the boreholes. The camera system was designed primarily for water-well applications, although its waterproof housing, relatively light weight and ability to work to temperatures of $0^{\circ} \mathrm{C}$ made it suitable for use at Haut Glacier d'Arolla. The basic system consisted of a miniature color video camera, lighting system, small TV/VCR, microphone, mounting tripod, and $230 \mathrm{~m}$ of cable on a hand-operated winch (Fig. 3). An onscreen display showed the depth below the glacier surface from a counter mounted on the winch. The video images were recorded on small-sized video cassettes for later viewing and analysis.

\section{RESULTS AND DISGUSSION}

Borehole video provided detailed information about the englacial and basal ice structure of Haut Glacier d'Arolla. Based on the scheme of Allen and others (1960), the ice observed in the walls of the boreholes was classified as coarse-clear, coarse-bubbly or fine-grained. Coarse-bubbly ice was relatively white in color due to a high air-bubble content, and was composed of crystals mostly $1-6 \mathrm{~cm}$ in diameter (Fig. 4a). Coarse-clear ice consisted of crystals more than $1 \mathrm{~cm}$ in diameter, was relatively clear and transparent due to a low air-bubble content, and had a blue color (Fig. 4b). Fine-grained ice was bubbly and distinctly white in color, and consisted of an aggregate of grains less than $1 \mathrm{~cm}$ in diameter. The ice types were mainly identified on the basis of air-bubble content, with coarse-clear ice defined by very few air bubbles (approximately $<2 \%$ by volume), coarse-bubbly ice defined by many individually identifiable air bubbles, and fine-grained ice defined by a large number of air bubbles that were not individually identifiable. Where individual ice crystals could be seen, their size was estimated with reference to the width of an in-front lighting attachment $(\approx 2.5 \mathrm{~cm})$ or the borehole diameter $(\approx 10 \mathrm{~cm})$. Although there were gradations between these ice types, a

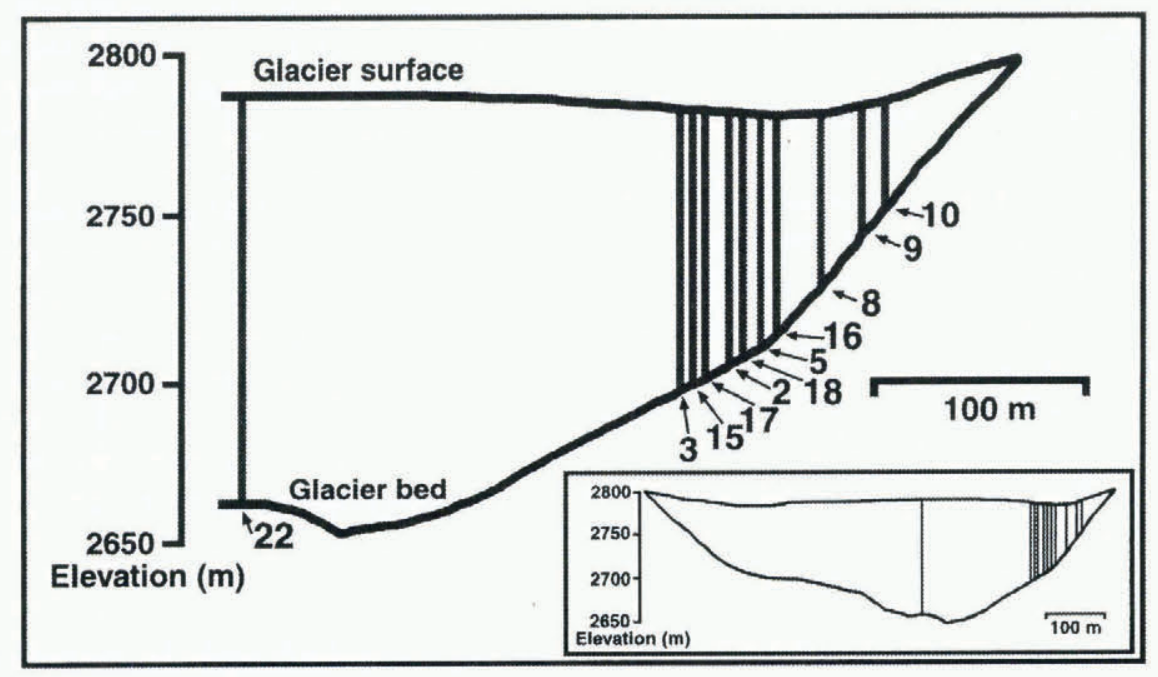

Fig. 2. Cross-section of Haut Glacier d'Arolla, showing location of boreholes inspected with the video camera in summer 1995. The numbers signify borehole location. 


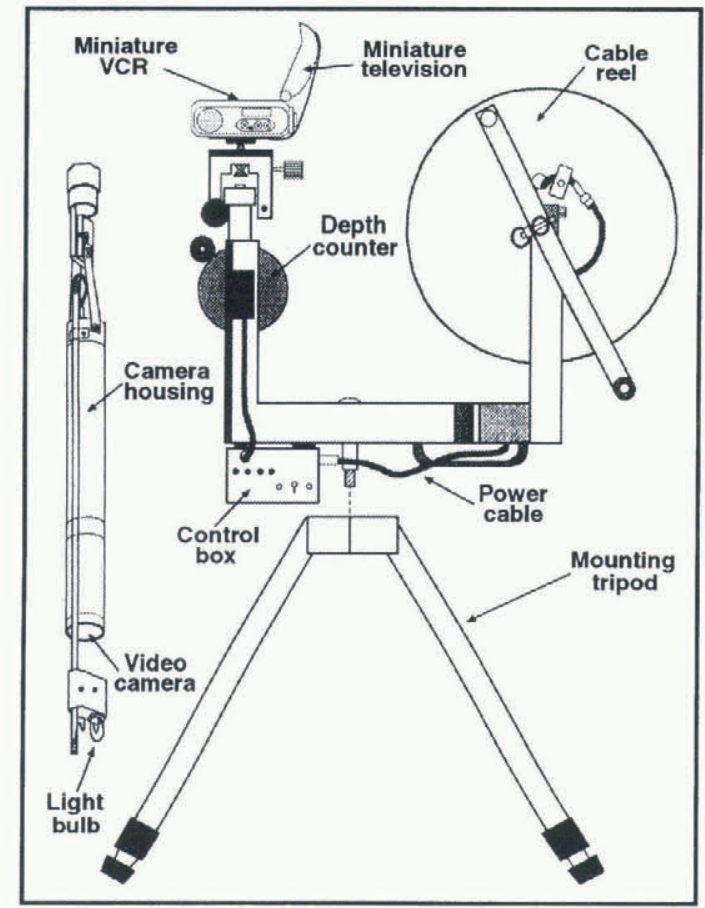

Fig. 3. The GeoVision Micro ${ }^{\text {(ix) }}$ borehole video-camera system ( reproduced with permission from Marks Products, Inc.).

three-fold classification was used as it provided a simple yet effective way of logging ice type. Planar structures such as crevasse traces and foliations of mainly coarse-blue ice were also observed in the boreholes.

\section{Basal ice conditions}

The glacier bed was observed in boreholes 95/10, 95/17 and 95/22 (Fig. 2). Constrictions or high-turbidity water prevented observation of the bed in the other boreholes. The video images showed that the glacier bed consisted of clasts in a matrix of fine sediment (Copland and others, in press). These findings support inferences from hydrological measurements (Hubbard and others, 1995), and observations in marginal subglacial cavities (Hubbard, 1992), that Haut Glacier d'Arolla lies at least partly on an unconsolidated bed.

A basal ice zone (BIZ), characterized by horizontally extensive bands of debris contained within coarse-clear ice, was observed in the lower part of boreholes 95/10 and 95/17. The debris bands were generally less than $5 \mathrm{~mm}$ thick, occurred at approximately $0.5 \mathrm{~m}$ intervals in the BIZ, and consisted of fine sediment similar to that observed at the glacier bed. The BIZ contained a much higher sediment concentration than ice observed higher in the boreholes, although the coarse-clear ice was not distinct from that above. By comparing the width of the debris bands and the vertical distance between them, the minimum sediment concentration was estimated as approximately $2 \%$ by volume in the BIZ, compared to approximately $0.2 \%$ by volume for ice higher in the glacier. Although the accuracy level of these measurements is difficult to assess, the orderof-magnitude difference in sediment concentration between the BIZ and ice higher in the glacier was clearly evident. The BIZ at Haut Glacier d'Arolla is very similar to the "stratified" ice identified by Hubbard and Sharp (1995).

Borehole video and observations at the glacier margin indicate that the BIZ becomes thicker away from the glacier edge. A BIZ has never been observed in marginal subglacial cavities or ice exposures at Haut Glacier d'Arolla (Hubbard and Sharp, 1995). In borehole 95/10, which was $32.0 \mathrm{~m}$ deep and approximately $80 \mathrm{~m}$ from the glacier margin, the BIZ was approximately $3 \mathrm{~m}$ thick. In borehole 95/17, which was $93.0 \mathrm{~m}$ deep and approximately $200 \mathrm{~m}$ from the glacier margin, the BIZ was approximately $8 \mathrm{~m}$ thick. A horizontal debris band was also observed $20 \mathrm{~m}$ above the glacier bed in borehole $95 / 22$, although high-turbidity water below this level meant that conclusive identification of a BIZ was not possible. Discussion here will focus on the locations where the BIZ could be clearly distinguished.

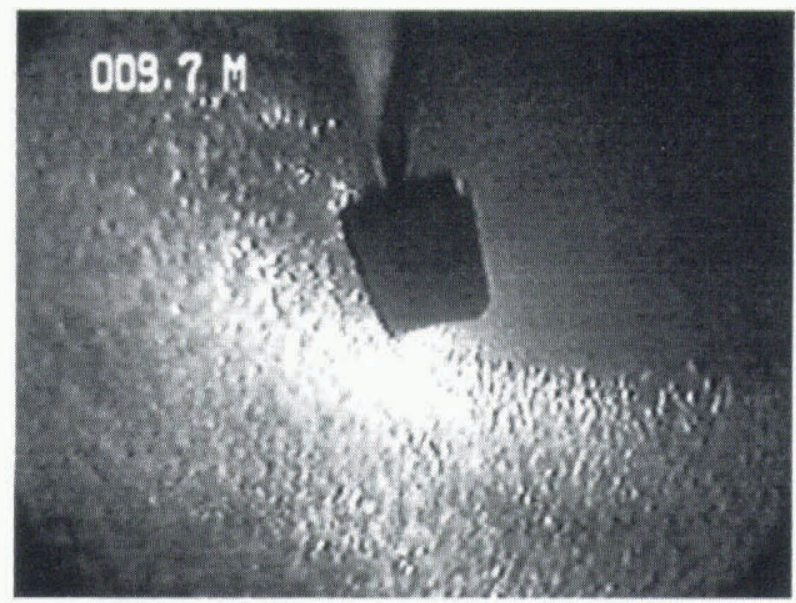

a

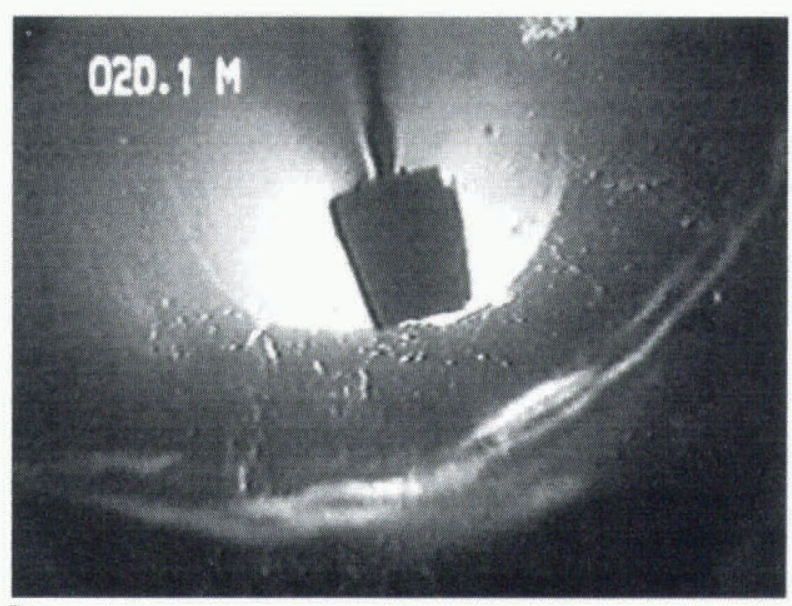

b

Fig. 4. (a) Video image of coarse-bubbly ice from a depth of $9.7 \mathrm{~m}$ in borehole 95/9. (b) Video image of coarse-clear ice from a depth of $20.1 \mathrm{~m}$ in borehole 95/9. Dark rectangle in center of each image is a mirror attachment on the front of the camera.

In terms of debris concentration and thickness, the Haut Glacier d'Arolla BIZ differs from basal ice zones described from many other temperate glaciers. Pessl and Frederick (1981, p. 92) stated that "a typical value for the amount of rock debris in temperate glacier ice is $25 \%$ (volume) debris content in a $400 \mathrm{~mm}$-thick basal debris-rich zone", whereas the Haut Glacier d Arolla BIZ is at least $8 \mathrm{~m}$ thick and has a debris content of approximately $2 \%$. It is unlikely that a very debris-rich zone existed below the base of the boreholes at Haut Glacier d'Arolla, since the drill did not progress any further when it was left at the inferred position of the bed for over $5 \mathrm{~min}$ (when normal drilling would have produced an 
increase in depth of at least $1 \mathrm{~m}$ ). In addition, basal sediment could be "felt" when the drill reached the inferred basal location, and borehole depths matched those predicted by radio-echo sounding. Thus, differences probably relate to the definition of the BIZ. Most studies on temperate and sub-temperate glaciers (e.g. Lawson and Kulla, 1978; Boulton and others, 1979; Tison and Lorrain, 1987; Hart, 1995) have identified basal ice as a distinct layer of very debrisrich (up to $50 \%$ by volume) ice from observations in subglacial cavities and ice cliffs close to the glacier margins. The identification of a distinct basal ice layer differs from the observations at Haut Glacier d'Arolla of a much more extensive zone of basal ice. Previous studies may therefore have placed undue emphasis on the formation of basal ice by marginal accretion processes, rather than on processes which occur in the glacier interior.

To explain the presence of the BIZ, and the reasons for its spatial variability, it is first necessary to determine whether the debris bands were supraglacial or subglacial in origin. The most likely supraglacial origin is rock fall from the headwall of the glacier, as this would be expected to follow a flowline close to the glacier bed (Paterson, 1994). Possible subglacial origins include regelation and adfreezing (Hubbard and Sharp, 1995). From the available evidence, a subglacial origin is favored due to the large horizontal extent of the debris bands observed in the BIZ, the marked spatial variability in the thickness of the BIZ, and the fact that no large clasts $(>1 \mathrm{~cm}$ diameter) were observed in the debris bands. Hubbard and Sharp (1995) also concluded that stratified ice was subglacial in origin.

Based on a variety of theoretical, field and laboratory studies, several hypotheses have been proposed to explain the entrainment of subglacial material (see, Drewry, 1986; Hubbard and Sharp, 1989, for reviews). From the available evidence, many of these hypotheses can be rejected as being dominent in the production of the BIZ at Haut Glacier d'Arolla. Regelation (Boulton, 1972; Hubbard and Sharp, 1993), or the "heat pump" effect (Robin, 1976), are unlikely to provide satisfactory explanations due to their production of a typically thin BIZ. Weertman's (1961) and Boulton's (1977) marginal-freezing hypotheses are unlikely to apply to a temperate glacier, except perhaps in spring in very marginal areas as a consequence of the winter cold wave. The hypothesis of Strasser and others (1996) that basal freezing could occur from the loss of heat as water flows uphill out of an overdeepening and into thinner ice is not applicable here since radio-echo sounding of the glacier bed has shown that there is no significant overdeepening above the borehole locations. Shaw (1977) argued that basal ice sequences may develop from the overriding of frontal aprons by an advancing glacier, but this mechanism is unlikely since Haut Glacier d'Arolla has been retreating for most of the last century. Basal freezing from the intrusion of cold air into open subglacial cavities and channels has also been proposed as a mechanism of basal ice formation (Vivian and Bocquet, 1973; Anderson and others, 1982), but is unlikely to occur away from marginal areas, due to closure of openings by ice deformation.

The most probable explanation for the BIZ observed at Haut Glacier d'Arolla is that localized areas of the glacier bed periodically freeze to the underlying sediment by the water-pressure mechanism proposed by Robin (1976). Robin (1976) envisaged that areas of the glacier bed with normally high water pressures would freeze at the ice/rock interface from the relief of stress when the pressure rose in surrounding low-pressure areas. This is because the smaller highpressure areas of stress concentration would experience a proportionately greater decrease of pressure than surrounding areas in order to maintain the balance between pressure and weight. This theory provides the most likely explanation for BIZ formation at Haut Glacier d'Arolla, because borehole water-level measurements record high diurnal water-pressure variations in a zone some tens of meters wide that has been termed the variable pressure axis (VPA; Hubbard and others, 1995). The VPA is located approximately $40 \mathrm{~m}$ east of borehole 95/17, $80 \mathrm{~m}$ west of borehole 95/10 (Fig. 2 ), and grades over a distance of about $70 \mathrm{~m}$ to higher and more stable water pressures in a surrounding distributed hydrological system. High diurnal water-pressure variations in the area around borehole 95/17 would therefore result in relatively frequent localized basal freezing according to Robin (1976), whereas more damped variations around borehole 95/10 would result in less localized basal freezing. Marginal areas would not experience any basal freezing by this process, given their low, if any, water pressures. Spatial variations in basal water pressure as they relate to variations in basal freezing therefore provide a possible explanation for the observed variations in BIZ thickness. Video observations of frazil ice in boreholes provide some evidence in support of this process, as the frazil ice appears to form due to pressure-release induced freezing when waters rise up the boreholes.

Once material has been frozen to the glacier sole, it is likely that glaciotectonic processes account for the BIZ reaching a thickness of at least $8 \mathrm{~m}$. As discussed by Hubbard and Sharp (1995), the interstratification of low-debriscontent coarse-clear ice and horizontally extensive debris bands indicates tectonically induced layering from faulting and folding (Hudleston, 1977; Tison and others, 1989). No distinct fracture planes were observed in the BIZ, although this may have been because the fracture planes were hidden by the debris bands along which they occurred, or because there was partial recrystallization of the ice.

\section{Ice type variability}

Video observation of the ice conditions in the boreholes showed a progressive decrease in air-bubble content and increase in ice-crystal size with depth in the glacier. These observations are similar to those from video in other glaciers (Pohjola, 1994; Harper and Humphrey, 1995). Superimposed on these progressive changes in ice type with depth were two zones that showed rapid changes in ice type. On the basis of changes in air-bubble content, there was a marked transition between higher fine-grained ice and lower coarse-bubbly ice at a depth of approximately $2 \mathrm{~m}$. Secondly, there was a marked transition between higher coarse-bubbly ice and lower coarse-clear ice at a depth of 10-25 m. These transitions were observed in all boreholes, and did not show any systematic variation with distance across the glacier. Distinct changes in ice color were associated with these icebubble content changes, from bright white near the glacier surface to blue or clear near the glacier bed.

It is generally accepted that progressive variations in ice-crystal size and air-bubble content with depth relate to ice recrystallization and the escape or compression of air bubbles from the weight of overlying ice (Paterson, 1994). If overburden pressure were the only influence, a uniform 
change in ice type would be expected through a glacier. The video observations appear to show that changes in ice type are not entirely uniform, however, due to the rapid transitions between fine-grained ice and coarse-bubbly ice, and between coarse-bubbly ice and coarse-clear ice. The patterns of borehole refreezing after drilling allow for the possibility that these transitions relate to the short-term (several days) and annual influence of cold and warm waves that originate from changes in air temperature and solar radiation inputs at the glacier surface. This is because the water in full boreholes often froze at a depth of 5-20 m below the glacier surface, with the freezing location occurring progressively closer to $20 \mathrm{~m}$ depth later in the melt season. Freezing also occasionally occurred close to the glacier surface $(0-2 \mathrm{~m}$ depth) after particularly cold nights when the air temperature fell below $0^{\circ} \mathrm{C}$ (temperatures are generally above $0^{\circ} \mathrm{C}$ during the melt season at the study site). This freezing pattern suggests that the glacier is temperate and at the freezing point throughout, except for a surface zone approximately $20 \mathrm{~m}$ thick that is cooled below freezing by a winter cold wave. The onset of the summer melt season and warmer air temperatures leads to the progressive reduction of this surface cold zone from the surface downwards, until the ice reaches $0^{\circ} \mathrm{C}$ throughout. Superimposed on this gradual reduction in surface cold-zone extent are short-term periods of cooling below $0^{\circ} \mathrm{C}$ of the upper $2 \mathrm{~m}$ of the glacier due to periodic overnight freezing.

The boundary between fine-grained ice and coarse-bubbly ice at a depth of $2 \mathrm{~m}$ therefore seems to correlate with shortterm variations in ice temperature caused by periodic overnight freezing. Similarly, the boundary between coarsebubbly ice and coarse-clear ice at a depth of 10-25 m seems to correlate with the depth of influence of the annual winter cold wave. Changes in ice temperature may have an effect on ice type via small-scale expansion and contraction of the ice, and the freezing and melting of water contained within the ice. Frequent variations in temperature (e.g. periodic night-time freezing) could therefore lead to extensive microfracturing and the production of fine-grained ice, while longer-term variations in temperature (e.g. on the annual scale) could lead to less fracturing and perhaps the production of coarse-bubbly ice.

Rejection of this theory is not possible given the current observations, and thus the marked correlation between variations in ice type and inferred variations in ice temperature at two transitions in ice type allows for the suggestion that the link may be causal. Other possible explanations for the observed patterns of ice type variation both here and at other glaciers might include a pressure-release mechanism as ice moves towards the glacier surface in the ablation zone, or patterns of crevasse closure and subsequent deformation. Further study is necessary to indicate which, if any, of these explanations is correct.

\section{Ice foliation}

Two main types of vertical or near-vertical ice foliation were observed in the boreholes. First, distinct planar features of predominantly coarse-clear blue ice were present in the upper $40 \mathrm{~m}$ of the ice column. They comprised approximately $10 \%$ of the ice column to a depth of $40 \mathrm{~m}$ in the area around borehole $95 / 17$, and approximately $5 \%$ of the ice column to a depth of $40 \mathrm{~m}$ near the glacier center (borehole 95/ 22) or glacier margin (borehole 95/10) (Fig. 2). They had an average diameter of approximately $5 \mathrm{~cm}$, with a range from $5 \mathrm{~mm}$ to $1.0 \mathrm{~m}$. The available evidence indicates that foliations of this type are caused by the closure of crevasses, and perhaps by the freezing of water within them. This is because very few foliations were observed below a depth of $40 \mathrm{~m}$, which is consistent with the maximum theoretical and measured crevasse depth of $30-35 \mathrm{~m}$ on temperate glaciers (Holdsworth, 1969; Menzies, 1995). Water-filling provides an explanation of how fracture could extend past the limit for open crevasses, to a depth of $40 \mathrm{~m}$ (Hambrey, 1976). Many open and closed crevasses were also observed upglacier from the borehole array, with the largest and most concentrated zone in the area up-glacier from borehole 95/17. A partially closed crevasse observed intersecting borehole 95 8 at a depth of $26.5 \mathrm{~m}$ indicates that crevasse closure is active around the borehole array (Copland and others, in press). Hambrey and Müller (1978) also concluded that distinct planar blue-ice foliations were caused by crevasse closure.

The second type of ice foliation observed in the boreholes consisted of thin bands of coarse-bubbly ice, and occasionally fine-grained ice, that occurred throughout the ice column but were most common near the glacier margins. These foliations were generally thin $(<2 \mathrm{~cm}$ diameter $)$, and comprised less than $0.5 \%$ of the ice column. Foliations of this type are widely exposed on the glacier surface in the area around the boreholes, where they make up longitudinal foliation. As discussed by Lawson and others (1994), this longitudinal foliation most likely originates from strong transverse compression (transpression) as ice in the wider upper area of the glacier (approximately $2 \mathrm{~km}$ wide) flows into the narrower down-glacier area where the borehole array is located (approximately $1 \mathrm{~km}$ wide) (Fig. 1). Sedimentary stratification caused by the annual formation of new ice in the accumulation area of the glacier is then deformed by this process in a regime of transpression with superimposed marginal shear. The closure of snow-filled crevasses has also been identified as a mechanism by which fine-grained foliation can form (Allen and others, 1960).

\section{GONGLUSIONS}

Video observations throughout the ice column across a section of Haut Glacier d'Arolla have allowed insight into spatial variations in ice type and structure. A basal ice zone of variable thickness was observed in two boreholes. This zone had a much lower debris content (approximately $2 \%$ by volume) than most previously identified basal ice layers, although it was still an order of magnitude higher in debris content than ice higher in the glacier. The available evidence indicates that the BIZ was formed by a combination of water-pressure induced freezing at the glacier bed, and glaciotectonic thickening. More observations are needed to verify if this mechanism is truly dominant in the production of the BIZ at Haut Glacier d'Arolla, and whether it is widespread in the production of basal ice at other glaciers. Transitions between fine-grained and coarse-bubbly ice, and between coarse-bubbly and coarse-clear ice, were observed superimposed on a progressive increase in ice-crystal size and decrease in air-bubble content with depth in the glacier. These transitions correlate with the inferred depth of influence of semi-diurnal and annual cold waves, respectively, although more studies are required to determine if this link is causal. Finally, two types of ice foliation were identified in 
the glacier. Distinct planar coarse-clear ice foliations observed in the upper $40 \mathrm{~m}$ of the ice column appear to result from the closure of crevasses above the borehole array. More pervasive coarse-bubbly and fine-grained ice foliations appear to result mainly from the transposition of sedimentary stratification.

\section{HIGHLIGHTS VIDEO}

A 23 min composite video tape of the "highlights" of the Haut Glacier d'Arolla borehole video recordings has been produced for educational and research use. Please contact Harbor to obtain a copy of this video.

\section{ACKNOWLEDGEMENTS}

This research was funded by U.S. National Science Foundation grants OPP-9321350 and OPP-94963450, and the Natural Sciences and Engineering Research Council of Canada. The field assistance of B. Hubbard, M. Minner, S. Cross, D. Gaselee, S. Gordon, and all other 1995 Arolla Glaciology Project members is greatly appreciated.

\section{REFERENGES}

Allen, C. R., W. B. Kamb, M. F. Meier and R. P. Sharp. 1960. Structure of the lower Blue Glacier, Washington. 7. Geol., 68(6), 601-625.

Anderson, R. S., B. Hallet, J. Walder and B. F. Aubrey. 1982. Observations in a cavity beneath Grinnell Glacier. Earth Surface Processes and Landforms, 7(1), $63-70$.

Boulton, G. S. 1970. On the origin and transport of englacial debris in Svalbard glaciers. 7. Glaciol., 9(56), 213-229.

Boulton, G. S. 1972. The role of thermal regime in glacial sedimentation. In Price, R. J. and D. E. Sugden, comps. Polar geomorphology. London, Institute of British Geographers, 1-19.

Boulton, G. S. 1977. Guide to Breiðamerkurjökull, Iceland. INQUA, Commission on Lithology and Genesis of Quaternary Deposits.

Boulton, G. S., E. M. Morris, A. A. Armstrong and A. Thomas. 1979. Direct measurement of stress at the base of a glacier. 7. Glaciol., 22(86), 3-24.

Copland, L., J. Harbor, M. Minner and M. Sharp. 1997. The use of borehole inclinometry in determining basal sliding and internal deformation at Haut Glacier d'Arolla, Switzerland. Ann. Glaciol., 24 (see paper in this volume).

Copland, L., J. Harbor, S. Gordon and M. Sharp. In press. The use of borehole video in investigating the hydrology of a temperate glacier. Hydrol. Processes.

Drewry, D. 1986. Glacial geologic processes. London, Edward Arnold.

Engelhardt, H. F., W. D. Harrison and B. Kamb. 1978. Basal sliding and conditions at the glacier bed as revealed by bore-hole photography. $\mathcal{F}$. Glaciol., 20 (84), 469-508.

Goodman, D. J., G. C. P. King, D. H. M. Millar and G. de Q. Robin. 1979. Pressure-melting effects in basal ice of temperate glaciers: laboratory studies and field observations under Glacier d'Argenti're. 7. Glaciol., $23(89), 259-272$.

Hagen, J. O., B. Wold, O. Liestøl, G. Østrem and J. L. Sollid. 1983. Subglacial processes at Bondhusbreen, Norway: preliminary results. Ann. Glaciol., 4, 91-98.

Hambrey, M. J. 1976. Structure of the glacier Charles Rabots Bre, Norway. Geol. Soc. Am. Bull., 87(11), 1629-1637.

Hambrey, M. J. and F. Müller. 1978. Structures and ice deformation in the White Glacier, Axel Heiberg Island, Northwest Territories, Canada. 7 . Glaciol., 20 (82), 41-66.

Harper, J.T. and N. F. Humphrey. 1995. Borehole video analysis of a temperate glacier's englacial and subglacial structure: implications for glacier flow models. Geology, 23(10), 901-904.

Harrison, W. D. and B. Kamb. 1973. Glacier bore-hole photography. f. Glaciol., 12(64), 129-137.
Hart, J. K. 1995. An investigation of the deforming layer/debris-rich basalice continuum, illustrated from three Alaskan glaciers. f. Glaciol., 41(139), $619-633$.

Holdsworth, G. 1969. Primary transverse crevasses. f. Glaciol., 8(52), 107129.

Hubbard, B. P. 1992. Basal ice facies and their formation in the western Alps. (Ph.D. thesis, University of Cambridge.)

Hubbard, B. and M. Sharp. 1989. Basal ice formation and deformation: a review. Prog. Phys. Geogr., 13(4), $529-558$.

Hubbard, B. and M. Sharp. 1993. Weertman regelation, multiple refreezing events and the isotopic evolution of the basal ice layer. F. Glaciol., 39(132), 275-291.

Hubbard, B. and M. Sharp. 1995. Basal ice facies and their formation in the western Alps. Arct. Alp. Res., 27(4), 301-310.

Hubbard, B. P., M. J. Sharp, I. C. Willis, M. K. Nielsen and C. C. Smart. 1995. Borehole water-level variations and the structure of the subglacial hydrological system of Haut Glacier d'Arolla, Valais, Switzerland. J. Glaciol., 41(139), 572-583.

Hudleston, P. J. 1977. Similar folds, recumbent folds, and gravity tectonics in ice and rocks. 7. Geol., 85(1), $113-122$.

Jouzel, J. and R. A. Souchez. 1982. Melting-refreezing at the glacier sole and the isotopic composition of the ice. f. Glaciol., 28(98), 35-42.

Kamb, B. and E. LaChapelle. 1964. Direct observation of the mechanism of glacier sliding over bedrock. 7. Glaciol., 5(38), 159-172.

Koerner, R. M. 1977. Distribution of microparticles in a $299-\mathrm{m}$ core through the Devon Ice Cap, Northwest Territories, Canada. International Association of Hydrological Sciences Publication 118 (Symposium at Grenoble 1975 - Isotopes and Impurities in Snow and Ice), 371-376.

Koerner, R. M., D. A. Fisher and M. Parnandi. 1981. Bore-hole video and photographic cameras. Ann. Glaciol., 2, $34-38$.

Lamb, H. R. and 8 others. 1995. The composition of subglacial meltwater sampled from boreholes at the Haut Glacier d'Arolla, Switzerland. International Association of Hydrological Sciences Publication 228 (Symposium at Boulder 1995 - Biogeochemistry of Seasonally Snow-Covered Catchments), 395- 403 .

Lawson, D. E. and J. B. Kulla. 1978. An oxygen isotope investigation of the origin of the basal zone of the Matanuska Glacier, Alaska. J. Geol., 86(6), $673-685$.

Lawson, W. J., M. J. Sharp and M. J. Hambrey. 1994. The structural geology of a surge-type glacier. 7. Struct. Geol., 16(10), 1447-1462.

Menzies, J. 1995. The dynamics of ice flow. In Menzies, J., ed. Modern glacial environments: processes, dynamics and sediments. Vol. 1. Oxford, ButterworthHeinemann, 101-138.

Paterson, W. S. B. 1994. The physics of glaciers. Third edition. Oxford, etc., Elsevier.

Pessl, F., Jr and J. E. Frederick. 1981. Sediment source for melt-water deposits. Ann. Glaciol., 2, 92-96.

Pohjola, V. A. 1993. TV-video observations of bed and basal sliding on Storglaciären, Sweden. f. Glaciol., 39(131), 111-118.

Pohjola, V.A. 1994. TV-video observations of englacial voids in Storglaciären, Sweden. 7. Glaciol., 40(135), 231-240.

Rea, B. R. and W. B. Whalley. 1994. Subglacial observations from Øksfjordjøkelen, north Norway. Earth Surface Processes and Landforms, 19 (7), 659 673.

Robin, G. de Q. 1976. Is the basal ice of a temperate glacier at the pressure melting point? 7. Glaciol., 16(74), 183-196.

Shaw, J. 1977. Tills deposited in arid polar environments. Can. 7. Earth Sci., 14(6), 1239-1245

Strasser, J. C., D. E. Lawson, G. J. Larson, E. B. Evenson and R. B. Alley. 1996. Preliminary results of tritium analyses in basal ice, Matanuska Glacier, Alaska, U.S.A.: evidence for subglacial ice accretion. Ann. Glaciol., 22, 126-133.

Tison, J. -L. and R. D. Lorrain. 1987. A mechanism of basal ice-layer formation involving major ice-fabric changes. 7. Glaciol., 33(113), 47-50.

Tison, J. -L., R. Souchez and R. Lorrain. 1989. On the incorporation of unconsolidated sediments in basal ice: present-day examples. Z Geomorphol., 72, Supplementband, 173-183.

Tranter, M. and 9 others. In press. Variability in the chemical composition of in situ subglacial meltwaters. Hydrol. Processes.

Vivian, R. and G. Bocquet. 1973. Subglacial cavitation phenomena under the Glacier d'Argentière, Mont Blanc, France. f. Glaciol., 12 (66), 439 -451.

Weertman, J. 1961. Mechanism for the formation of inner moraines found near the edge of cold ice caps and ice sheets. .7. Glaciol., 3(30), 965-978. 